\title{
Dental Health as a Neglected Issue in Medical History: The School Dental Service in England and Wales, $1900-40$
}

\author{
JOHN WELSHMAN*
}

\begin{abstract}
Introduction
Anecdotal evidence suggests that, in the first half of the twentieth century, Britain's working-class population had poor dental health. Richard Hoggart, for example, recalled of his childhood in the Hunslet area of Leeds that he and his contemporaries were very aware of "corns, bad eyesight, corrected by cheap spectacles (Woolworths usually), indigestion, flatulence and constipation. . . . ailments, I suppose, which came from poor diet, insufficient exercise and ill-fitting shoes". This list of minor but persistent sickness also included poor dental health, and many adults wore dentures as they had lost all their teeth. Hoggart remembered that "one was very much aware of false teeth; adults bending over you were likely to present rows of startlingly regular, cheap-looking gnashers", and he recalled that once he sipped from a glass of water on a bedside table and found "Uncle Walter's teeth knocking against my own". ${ }^{1}$ This impression is echoed by the comments of other writers, and by the findings of social surveys. George Orwell argued after his famous expedition to Wigan that malnutrition was reflected in poor dental health, and he recorded the opinion of one woman who had told him that "teeth is just a misery". ${ }^{2}$ Margery Spring Rice, in her study of the health of 1,250 working-class women published in 1939, found that 165 said they had poor teeth, and 47 of those had not had any advice or treatment. ${ }^{3}$ Indeed this figure, of 13.2 per cent with poor dental health, was almost certainly an underestimate.

Yet while anecdotal evidence suggests that poor dental health was an everyday feature of working-class life, historians who have recently begun to chart the extent and effectiveness of health services before the creation of the National Health Service (NHS) have largely ignored dental health as an aspect of morbidity. Indeed they have concentrated on services for children at the expense of provision for adults. Some historians of education, such as John Hurt, have examined dental services in schools in the

*Dr John Welshman, Wellcome Unit for the History of Medicine, 45-47 Banbury Road, Oxford OX2 6PE.

I would like to acknowledge the help of Bernard Harris, David Smith, and Medical History's editors and referees on an earlier draft of this article. The usual disclaimers apply. My work on the School Dental Service has been supported by grants awarded by the Economic and Social Research Council, and The Wellcome Trust.

1 R Hoggart, A local habitation (life and times, volume 1: 1918-40), London, Chatto and Windus, 1988, Oxford ed., 1989, p. 55.

2 G Orwell, The road to Wigan pier, London, Gollancz, 1937, Penguin ed., 1962, p. 87.

3 M Spring Rice, Working-class wives: their health and conditions, London, Penguin, 1939, Virago ed., 1981, p. 39.
\end{abstract}


course of their work on the health of schoolchildren. ${ }^{4}$ Dentists, including Stanley Gelbier, have also traced the history of their profession, and have looked at the early development of services in London, and at the way that orthodontics grew as a dental specialism. ${ }^{5}$ Charles Webster has pointed out that medical inspections provided an inaccurate picture of dental health, and that in the interwar period, local authorities in depressed areas such as South Wales were unable to develop school dental services. ${ }^{6}$ Finally Geoffrey Bowles has looked at the period after the Second World War, and at the development of dental services for mothers and infants under the NHS. ${ }^{7}$ Even so, dental health plays a comparatively minor role in the most recent history of the School Medical Service. ${ }^{8}$

This article seeks to remedy this gap in our understanding of this aspect of child health by re-examining the School Dental Service in England and Wales, from its origins in the early 1900 s to the outbreak of the Second World War. While primarily a study of the development of policy at the national level, it also tries to look at the provision of services, and includes material drawn from a case-study based on the Midlands city of Leicester. The first section considers the way that the setting up of the School Dental Service was influenced by the debate on "physical deterioration" and by developments in other European countries, and it provides an overview of its expansion before the Second World War. Secondly the article looks in more detail at three themes in this period; the employment of school dentists and other staff including "dental dressers", the impact of research on diet and dental health on policy, and regional variations in the provision of services. In the third section, the article assesses the extent to which the new attention given to dental health during the Second World War marked a watershed. Finally, through the case-study of services in Leicester County Borough, it considers how these issues were reflected in provision on the ground. In conclusion, the article tries to draw out some lessons from the past for contemporary policy on dental health.

\section{The Development of the School Dental Service}

By the late nineteenth century, some European countries including Denmark, France, and Switzerland had already set up schemes whereby dentists in some of the larger towns inspected the teeth of schoolchildren. In Britain, too, a School Dentists Society had been founded in 1870 , principally to represent the interests of the school dentists who had been

$4 \mathrm{~J} \mathrm{~S}$ Hurt, Elementary schooling and the working classes 1860-1918, London, Routledge \& Kegan Paul, 1979, pp. 137, 140.

5 S Gelbier, 'Frederick Bresse and London's first school dental clinic', Br. den. J., 1981, 151: 309-11; S Gelbier and S Randall, 'Charles Edward Wallis and the rise of London's School Dental Service', Med. Hist., 1982, 26: 395-405; S Gelbier, 'Britain's first community orthodontic scheme: for the children of Heston and Isleworth', Med. Hist., 1985, 29: 414-32.

6 C Webster, 'Healthy or hungry thirties?', Hist. Workshop J., 1982, 13: 110-29, p. 118; idem, 'The health of the school child during the depression', in N Parry and D McNair (eds), The fitness of the nation-physical and health education in the nineteenth and twentieth centuries, Leicester, The
History of Education Society of Great Britain, 1983, pp. 70-85, on pp. 75-7; idem, 'Health, welfare and unemployment during the depression', Past and Present, 1985, 109: 204-30, p. 219.

7 G Bowles, 'National health dental services 1948-1955', Bull. soc. Hist. Med., 1981, 29: 1-6.

8 B Harris, The health of the schoolchild: $a$ history of the School Medical Service in England and Wales, Buckingham, Open University Press, 1995, pp. 154-5, 177, 190-5. For a Foucaldian interpretation see also S Nettleton, Power, pain and dentistry, Buckingham, Open University Press, 1992, and on the dental health of Jewish schoolchildren in Leeds, B Harris, 'Anti-alienism, health and social reform in late Victorian and Edwardian Britain', Patterns of Prejudice, 1997, 31: 3-34. 
appointed by public schools such as Haileybury, Marlborough, Wellington, and Tonbridge. Yet although compulsory education had brought an increasing appreciation of the importance of children's health and welfare, state schools had made no attempt to provide dental inspections or treatment. In the early 1900s, dental health began to feature prominently in the debate on "physical deterioration" that followed the military setbacks of the Boer War. Some commentators took an approach to dental health that reflected their conservative stance on other issues such as poverty and malnutrition. Major General Sir Frederick Maurice, for example, reported that many recruits had been sent back from South Africa on account of their bad teeth, but he linked poor dental health among children to "unwholesome feeding", rather than to malnutrition. ${ }^{9}$ Others were more progressive and used the same evidence to lobby for better dental services. Arthur Newsholme, the Local Government Board's Medical Officer, argued that local authorities should employ school dentists and consider health education, and it was pointed out that some European countries had already taken steps in this direction. ${ }^{10}$

While it is well known that the committees set up by the Government in response to the alleged "physical deterioration" considered much evidence on children's welfare, it is not generally appreciated that dental health had a central role in these debates. The Report of the Royal Commission on Physical Training in Scotland, published in 1903, found that few children used toothbrushes and many needed dental treatment. ${ }^{11}$ Similarly some of the witnesses called before the Inter-Departmental Committee on Physical Deterioration discussed the links between dental caries and food, while the British Dental Association (BDA) also produced important new evidence. In an appendix to the report, the BDA's Hygiene Committee claimed that in the period 1891-1902, the number of recruits rejected on account of their dental health had increased five times. It noted that 3,000 men had been invalided home from South Africa because of their teeth, and that the Government had both sent out dentists to attend to the troops in the field, and used local dentists for those at base. The BDA linked the dental health of the recruits with that of schoolchildren. It found from an examination of over 10,000 English and Scottish schoolchildren that there was a high incidence of caries, and recommended dental health education in schools and a wider enquiry. ${ }^{12}$ The "physical deterioration" debate gave dental health a wider resonance in society in general. In Scouting for boys, first published in 1908, Robert Baden-Powell advised apprentice boy scouts to look after their teeth, writing that "a scout with bad teeth is no use at all for scouting work, because he has to live on hard biscuits and hard meat, which he cannot possibly eat or digest if his teeth are not good". ${ }^{13}$ Thus dental health was emphasized because soldiers with bad teeth were thought to be unreliable.

\footnotetext{
9 Miles [F Maurice], 'Where to get men', Contemp. Rev., 1902, 81: 78-86; idem, 'National health: a soldier's study', Contemp. Rev., 1903, 83: 41-56.

10 A Newsholme, 'The relation of the dental profession to public health', Br. den. J., 1903, 24: 533-45; W Rushton, 'Education of the public in the care of their teeth', Br. den. J., 1903, 24: 545-51.

11 PP 1903, Xxx (Cd. 1507, 1508), Report of the
}

\author{
Royal Commission on Physical Training (Scotland), \\ vol. 1, appendix ix, pp. 90, 106. \\ 12 PP 1904, XxxII (Cd. 2175, 2186, 2210), Report \\ of the Inter-Departmental Committee on Physical \\ Deterioration, vol. 1, pp. 83-4, appendix xxviii, \\ pp. 98-100. \\ 13 R Baden-Powell, Scouting for boys, London, \\ Arthur Pearson, 1908, rev. ed., 1910, pp. 177-8, 183.
}


Discussions about dental health also reflected the creation of other health and welfare services for children. The conclusions of the earlier Parliamentary reports were echoed by the report of the Inter-Departmental Committee on Medical Inspection and Feeding, published in February 1906, and some of those who had campaigned for school meals also took a progressive line on this issue. ${ }^{14} \mathrm{John}$ Gorst MP, for example, argued that parents should be educated about the importance of dental health, but also suggested that schoolchildren should receive more help from the state. ${ }^{15}$ Some local authorities had already begun to appoint school dentists, including Cambridge, which had established a dental service in 1900, and some of the recently appointed school doctors began to campaign for improved services. Edward Wallis, for instance, who had been appointed assistant SMO to the London County Council in 1905, reported that inspections of children in individual boroughs indicated that children had not cleaned their teeth or showed any evidence of treatment, apart from a few extractions. Wallis noted that whereas London seemed to be doing very little, 29 large cities in Germany had established school dental clinics. ${ }^{16}$ In other articles, he contrasted provision in European cities such as Strasbourg, Muhlhausen, and Darmstadt with that in London, and he campaigned for dental clinics, claiming that they would lead to a decline in dental disease and an improvement in general health, and raise the quality of recruits to the armed services. ${ }^{17}$ In later years he lobbied for further improvements in dental treatment, and the employment of better-trained staff. ${ }^{18}$

Although the Board of Education had initially resisted setting up a medical department, the 1906 Education (Provision of Meals) Act had enabled Local Education Authorities (LEAs) to provide meals, while the 1907 Education (Administrative Provisions) Act allowed them to set up medical inspections. As is well-known, the Board now established a medical branch with Dr George Newman, the former Medical Officer of Health (MOH) for Finsbury and Bedfordshire, as its first Chief Medical Officer (CMO). ${ }^{19}$ In his first annual report, Newman noted that in areas such as Cambridge and London school dental services were well advanced, and he suggested that treatment could be provided by clinics and hospitals in urban areas, and by travelling dentists in country districts. Conceding that a high percentage of schoolchildren had decayed teeth, he encouraged LEAs to appoint school dentists under the supervision of school doctors. Uncertainty about the effects of poor dental health gave it additional importance. In 1910 for example, Newman wrote that there was no other aspect of child health "which is responsible directly or indirectly for a larger proportion of the delicacy and disease (including constitutional disease) which is

14 PP 1906, XLVII (Cd. 2779, 2784), Report of the Inter-Departmental Committee on Medical Inspection and Feeding of Children Attending Public Elementary Schools, vol. 1, p. 29, appendix vi, pp. 277-81.

$15 \mathrm{~J}$ E Gorst, The children of the nation: how their health and vigour should be promoted by the state, London, Methuen, 1906, p. 123.

16 C E Wallis, The care of the teeth in the public elementary schools with special reference to what is being done in Germany, London, J \& A Churchill, 1908, p. 4.

${ }^{17} \mathrm{C}$ E Wallis, 'The school dental clinics of
Germany', Public Health, 1908, 21: 78-80; idem, 'The necessity for dental clinics in connection with elementary schools', Br. den. J., 1908, 29: 861-5.

$18 \mathrm{C}$ Wallis, 'The benefit derived from school dental treatment', Br. den. J., 1911, 32: 955-7; idem, School dental clinics: their foundation and management, London, Claudius Ash and Sons, 1912, pp. 6-7; idem, 'School dental treatment in London', Br. den. J., 1913, 34: 1074-6; idem., 'School Medical Officers and dental conditions among children', $\mathrm{Br}$. den. J., 1917, 38: 217-19.

19 Harris, op. cit., note 8 above, pp. 49-52. 


\section{John Welshman}

found at every turn to handicap efficiency, both physical and mental". ${ }^{20}$ However, in general, he was cautious about recommending that local authorities should set up extensive treatment schemes; he suggested that school clinics should deal only with those children whose parents could not afford private dentists, and that treatment should be further restricted to children aged six to eight and to those with permanent teeth. ${ }^{21}$

Despite these problems, aggregate statistics on staffing, dental clinics, and inspections and treatment appeared to indicate that there was some limited expansion before the Second World War. The number of dentists employed by local authorities in England and Wales increased from 162 part-time and 55 full-time staff in 1915, to 242 part-time and 124 full-time dentists in 1919, to the equivalent of 783 full-time staff by $1938 .{ }^{22}$ The number of school dental clinics provided by LEAs also increased significantly after 1912 , from 14 clinics in 1910 , to 586 clinics in 1920 , to 1,211 clinics in 1930 , to 1,362 clinics in 1935 , and to 1,673 clinics in 314 LEAs by $1938 .{ }^{23}$ Finally this expansion in staff and facilities was accompanied by an increase in the number of children inspected and treated, and in the proportion requiring fillings and extractions who were actually treated. The number of children inspected increased from $2 \mathrm{~m}$ in 1925 , to $2.8 \mathrm{~m}$ in 1930 , to $3.5 \mathrm{~m}$ in $1938 .^{24}$ Similarly, the number of children treated increased from $0.6 \mathrm{~m}$ in 1923 , to $1.2 \mathrm{~m}$ in 1930 , to $1.6 \mathrm{~m}$ in 1938 , and this represented a gradual increase in the proportion of children requiring treatment who were treated, from 55 per cent in 1925, to 65.5 per cent by 1938 . While many children only ever had teeth taken out and did not have access to conservative treatment, the balance did improve so that in 1938 school dentists performed $1.4 \mathrm{~m}$ fillings and $3.1 \mathrm{~m}$ extractions. ${ }^{25}$ Throughout the interwar period, therefore, the statistics generated by the School Dental Service appeared to provide impressive evidence of progress.

As in the case of nutrition, Newman placed much of the blame for the failure to take up treatment on the part of the parents, writing in 1925 that "the chief cause of the leakage is undoubtedly failure on the part of parents to appreciate the value of what is offered". 26 Nevertheless, the increase in the percentage of children accepting treatment may have been due to health education, and from the 1920s the Dental Board of the United Kingdom supplied LEAs with films and the leaflets What about your teeth and The story of a tooth.$^{27}$ In addition, some of the better-off LEAs felt able to embark on more progressive types of treatment. Heston and Isleworth, for example, had originally appointed a school dentist in October 1918 and it began to refer cases to hospital for orthodontic treatment in

20 PP 1911, XVII (Cd. 5925), Annual report of the Chief Medical Officer to the Board of Education for the year 1910, pp. 166-7.

21 PP 1910, XXIII (Cd. 5426), Annual report of the CMO, 1909, pp. 125-34.

22 PP 1916, VIII (Cd. 8338), Annual report of the CMO, 1915, p. 78; PP 1920, xv (Cd. 995), Annual report of the CMO, 1919, p. 84; Board of Education, Health of the school child: annual report of the Chief Medical Officer for 1938, London, HMSO, 1940, p. 40.

${ }^{23}$ Health of the school child, 1938, London, HMSO, 1940, p. 65, table XI.

${ }^{24}$ Health of the school child, 1925, London, HMSO, 1926, p. 57; Health of the school child,
1930, London, HMSO, 1931, p. 105, table xI; Health of the school child, 1938, London, HMSO, 1940, p. 63 , table vil.

${ }^{25}$ Health of the school child, 1923, London, HMSO, 1924, p. 43; Health of the school child, 1925, London, HMSO, 1926, p. 57; Health of the school child, 1930, London, HMSO, 1931, p. 105, table xI; Health of the school child, 1938, London, HMSO, 1940, pp. 40, 63, table vII.

${ }^{26}$ Health of the school child, 1925, London, HMSO, 1926, p. 58.

27 Public Record Office, Kew, London (hereafter PRO) ED 50/36, Board of Education, Circular 1347, The care of children's teeth, 1/1/25; Health of the school child, 1937, London, HMSO, 1938, p. 120. 
1924. In May 1930 it began a further scheme in conjunction with the Royal Dental Hospital in London; patients who were sent there were seen by a consultant, and the necessary work was done in the local school dental clinic. The LEA devised a scale of charges of between $3 \mathrm{~s}$ and $37 \mathrm{~s}$ based on family income, and by the end of the year had 143 cases on its books. The local SMO felt strongly that orthodontic care raised the tone of dental treatment as a whole, and hoped that it would be copied in other LEAs. ${ }^{28}$ One dentist based in Croydon argued in Public Health in 1933 that orthodontics was important in that it made the work of dentists in, schools more varied, and increased its prestige; his colleague suggested that orthodontic schemes should be linked to the work of ear, nose, and throat clinics. ${ }^{29}$ Thus the general expansion in the size and scope of the School Dental Service was accompanied by an increasing emphasis on dental health education and in some areas by the provision of orthodontic treatment.

\section{Salaries, “Dental Dressers", and Statistics}

However, while school dental provision certainly became more extensive over time, this linear narrative of the development of services fails to take sufficient account of some significant underlying themes. Throughout this period, the British Medical Association was a prominent lobbying organization that sought to protect the interests of general practitioners by campaigning against the provision of medical treatment and expansion of school clinics by the School Medical Service. In the field of dental treatment, the BDA operated in a similar manner, in arguing that children should be inspected by school dentists instead of school doctors, and by claiming that the official statistics were not very reliable. Some private dentists admitted that the state of children's teeth was a major problem, and monitored the progress of the clinics that had been established by other European cities. Yet in general they viewed school dental services with suspicion and open hostility. In 1904 for example, one argued that school inspections would be ineffective since many five-year-olds already had several carious teeth, and the tone remained critical after the School Dental Service had been established. ${ }^{30}$ In particular, the British Dental Journal regarded the statistics generated by school doctors with scepticism, pointing out in 1909 for example, that the reports for West Sussex seemed to suggest that only 46 per cent of six-year-olds, and 48 per cent of twelve-year-olds, had more than one carious tooth. The journal commented that the figures showed such marked differences from those of private dentists that "we may perhaps be pardoned for suggesting that they do not really represent the actual condition of the teeth". ${ }^{31}$ The British Dental Journal argued that these inaccurate figures could lead to complacency; in 1913 it suggested that examinations by SMOs were not as rigorous as inspections by school dentists, and noted that "for this reason we as dentists are unable to place much evidence upon the tables supplied by medical inspectors". ${ }^{32}$ The BDA acknowledged that the School Dental Service was seriously short of manpower, but it suggested that LEAs should pay private dentists to provide treatment on their behalf.

28 Gelbier, op. cit., note 5 above, 1985 , pp. 415-32; Health of the school child, 1930, London, HMSO, 1931, p. 27.

29 J F Pilbeam and K C B Webster, 'Orthodontics in the School Dental Service', Public Health, 1933, 46: 192-201.
30 Harris, op. cit., note 8 above, pp. 81-2, 111-12; J Sims-Wallace, 'Physical deterioration in relation to the teeth', Br. den. J., 1904, 25: 861-7.

31 Br. den. J., 1909, 30: 426.

32 Br. den. J., 1913, 34: 223. 
In his first annual report, Newman had conceded that the SMOs who examined the children in most local authorities used neither mirrors nor probes, and their inspections were rather "superficial". He was well aware that these medical inspections had limited value as far as dental health was concerned, and in providing insights into his uneasiness, internal departmental minutes were more revealing than the published annual reports. In April 1913, for example, he admitted that SMOs were not able to inspect teeth properly, and he claimed that because of pressure from the County Councils Association (representing the interests of local authorities in rural areas), he had to accept "dental inspection by school doctors, or indeed anybody else who was capable of doing it effectively". 33 At this time, the Board was concerned that superficial inspections meant that money spent on this aspect of the School Medical Service was being wasted. Although there were 352 dental clinics in 169 LEAs by 1918, Newman wrote of the dental health of children that "the problem stands in the front rank of the questions of preventive medicine with which the country is faced". 34

Two reports published in this period were critical of the School Dental Service. In early 1919, the Board of Education asked Norman Bennett, a prominent dental surgeon and chairman of the BDA, to visit and report on school dental clinics. He found that the results of treatment were disappointing, and argued that school dental schemes should be administered by full-time dentists and include orthodontic treatment. Treatment lacked uniformity and co-ordination, school dentists were too autonomous, and greater supervision was necessary. On the issue of anaesthetics for instance, Bennett argued that school dentists should always use them for extractions, as the infliction of unnecessary pain was "scientifically obsolete, and is a chief deterrent of further treatment". ${ }^{5}$ The report of the BDA's National Dental Service Committee, published in 1922, was also very critical of the School Dental Service. It found that since school dentistry did not offer security of tenure or good career prospects, many new school dentists had little experience, and it sought to remedy this by improving terms and conditions, and by instituting a Diploma in Public Dentistry. The Committee recommended that services should be run by dentists, set minimum staffing levels of one full-time dentist for every 4,000 children requiring treatment in a rural area, and 5,000 in an urban area, and opposed the appointment of "dental dressers". It concluded that the School Dental Service should not be primarily concerned with statistics on fillings and extractions, but with the effect "on the future health of the children". ${ }^{36}$ Although many of these criticisms were equally valid for other aspects of the School Medical Service, those pertaining to dental treatment were particularly serious.

With the evidence provided by the British Dental Journal, it is possible to identify some of the underlying and persistent problems that hampered the development of the School Dental Service. One of the reasons why local authorities found it difficult to recruit dentists was because they could not provide sufficiently attractive salaries. As early as

33 PRO ED 50/36, G Newman to Secretary, 17/4/13.

34 PP 1919, XXI (Cd. 420), Annual report of the CMO, 1918 , p. 89.

35 Ibid., pp. 98-105; PRO ED 50/36, N. Bennett, 'Report on school dental clinics', 6/19.

36 National Dental Service Committee, 'Report on the organisation and staffing of the School Dental Services, originally presented to the Representative Board on January 28, 1922', Br. den. J., 1922, 43: 1135-40. See also PRO ED 50/36, BDA National Dental Service Committee, 'Report on the organisation and staffing of the School Dental Services', 16/3/23, pp. 2-6. 
1909, Newman had noted that salaries for full-time dentists were around $£ 300$ per annum, and that the BDA insisted private dentists should be paid a minimum of $£ 1$ for half a day's work. ${ }^{37}$ The evidence from the British Dental Journal in the 1920 s also suggests that one of the main issues remained the disparity between the salaries offered by local authorities, and those available in private practice. While school dentists had salaries of around $£ 450$ per annum, their counterparts in private practice were earning around $£ 750$. In April 1922 one dentist wrote in the journal that "it is obvious that only men with private means, fond of children and regular holidays, or else newly qualified men, can be expected to take up these positions". ${ }^{38}$ The issue of dentists' salaries was one that was to continue to stunt the growth of the School Dental Service into the 1950s.

An additional but related issue was the question of whether school dental work should be performed by qualified dentists only, a particularly pressing issue in the light of the staff shortages. Newman suggested that local authorities could use unqualified staff such as nurses and "dental dressers" to do inspections, fillings, and extractions under the supervision of school dentists, but this policy was opposed by the BDA, which argued that only qualified dentists should perform operations and administer anaesthetics. ${ }^{39} \mathrm{~A}$ Departmental Committee was appointed in July 1917 to re-examine the 1878 Dentists Act in the light of the shortage of qualified dentists, and in particular to see whether legislation to prohibit practice by unqualified people was necessary, and if dental qualifications should be altered. It found that the main problems were finance, the shortage of dentists, and an alleged lack of demand. The Committee thought it "intolerable" that unqualified people could practise as dentists, but recommended that trained and competent "dental dressers" or nurses could be employed in school dental work. ${ }^{40}$ The 1921 Dentists Act provided for the employment of "dental dressers" in public dental services, but the BDA remained opposed to this practice. In May 1919 the BDA adopted the report of the National Dental Service Committee; it recommended that only qualified dental surgeons should perform operations such as fillings and extractions, but agreed that some changes could be made if they enabled dentists to work more quickly.

Despite the 1921 Dentists Act, the question of how far the School Dental Service should rely on unqualified staff was very much a live issue in the interwar period. In a circular issued in August 1922, the Board encouraged local authorities to employ dental students, nurses, and "dressers", as long as they were supervised by registered dentists. In a letter published in the Lancet in October 1924, Dr James Kerr, the former SMO to the London County Council, agreed that "dental dressers" were crucial to a policy of prevention, writing that "so long as it suffices, and serious risks are negligible, we do not stand on ancient rights or pedantic formulae". ${ }^{41}$ As the staffing problems worsened, some of the Board's civil servants came to argue that they could be solved if junior staff were allowed to perform inspections and treatment. In March 1931, C W Maudslay wrote that if dental nurses did inspections it would help local authorities particularly short of staff. Newman countered that medical and dental inspections raised technical questions of diagnosis

37 PP 1910, XXIII (Cd. 5426), Annual report of the CMO, 1909 , p. 134.

38 Br. den. J., 1922, 43: 319-20.

39 PP 1918, IX (Cd. 9206), Annual report of the CMO, 1917, p. 71.

40 PP 1920, xv (Cd. 995), Annual Report of the
CMO, 1919, p. 99.

41 PRO ED 50/36, Board of Education, Circular 1279, Performance of minor dental work by persons who are not registered dentists, 17/8/22; ibid., cutting from the Lancet, 25/10/24. 


\section{John Welshman}

which could be answered only by "properly trained and registered persons". ${ }^{42}$ Even so, the policy was supported by the County Councils Association, and in the early 1930s University College, London, and the Royal Dental Hospital set up courses for "dental hygienists" who would do "minor dental work".

Although the severity of the staffing problems meant that this policy always attracted some support, others continued to oppose "dental dressers" as being the thin end of a wedge that would erode qualified dentistry. While the BDA approved the use of assistants to enable dentists to work more quickly and efficiently, it argued that filling, extracting and scaling should be left to qualified dentists. In October 1924, for example, a dentist argued in a letter to the Lancet that cheap dentistry was "neither good for the dental profession nor for the public whose interests it exists to serve". ${ }^{43}$ There was some evidence that the BDA did change its stance. By the early 1930s, it accepted that dental nurses could be very useful and agreed to let them do health education as long as their sphere of work was carefully restricted. ${ }^{44}$ The Board was anxious about the way that LEAs such as Glamorgan and Liverpool used dental nurses to inspect children, and inspections in rural areas or in poorer cities certainly remained unsatisfactory. The MOH for Glamorgan, for example, revealed the true nature of school dentistry when he wrote in September 1933 that "it seems to me ridiculous to call the mere inspection of teeth and putting the result on a card as dental work ... the nurse merely does what the parent does-looks into the child's mouth and says "this child had better see the dentist". 45

The BDA had always been critical of the statistics generated by the School Dental Service, and remained so in the 1930s. One dentist argued in a letter to the British Dental Journal that between 80 and 90 per cent of children required treatment, that medical inspections were too quick and superficial, and that there was too much emphasis on the number of fillings and extractions. In an editorial published in January 1935, the journal noted that twice as many school dentists were needed and concluded that "inspection at the expense of treatment is a woeful waste of time". ${ }^{46}$ Others argued that less stress should be laid on statistics which should be of secondary importance to treatment. ${ }^{47}$ These criticisms were strikingly similar to those that individual SMOs and others made of the School Medical Service in general, and there were signs that the Board of Education was prepared to reform its methods. In 1933, Newman admitted that some dentists recorded only those children referred for treatment, and not those requiring fillings and extractions. Two years later Sir Arthur MacNalty, Newman's successor as CMO, noted that the number of attendances did not reflect the quality of the work done and were of minor importance, and he argued that these statistics could be very misleading since a dentist could do a small amount of treatment for a large number of children. ${ }^{48}$ Thus disparities between the salaries of private dentists and those working for local authorities, the degree to which the School Dental Service could draw on unqualified staff, and the reliability of official statistics remained key issues in the years before the Second World War.

\footnotetext{
42 Ibid., G Newman to C W Maudslay, 5/12/32.

43 PP 1919, XXI (Cd. 420), Annual report of the $C M O, 1918$, p. 95; PRO ED 50/36, cutting from the Lancet, 4/10/24.

44 PRO ED 50/40, extract from presidential address by $N$ Bennett, $5 / 30$.

45 Ibid., letter from E Colston Williams and J E
}

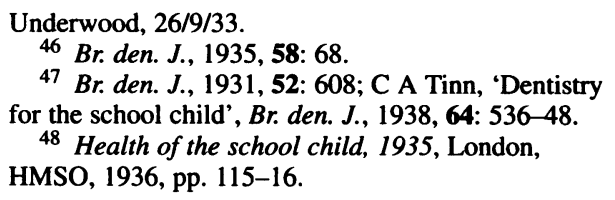




\section{Research on Diet and Teeth and the School Dental Service}

Some SMOs noted that the incidence of dental caries among children declined after the First World War, a phenomenon they attributed to the rationing of foods such as sugar, bread and milk, and to more intensive educational campaigns. ${ }^{49}$ While dental health was not a major area of scientific research, the Medical Research Council (MRC) did sponsor some surveys on teeth and diet which may have had an impact on policy. It is not possible in this brief section of the article to give a comprehensive account of dental research in this period. Rather it concentrates on the research of one individual, May Mellanby, and assesses the impact of her work on policy at the Board of Education. May Mellanby was the wife of Edward Mellanby, Professor of Biochemistry at the University of Sheffield from 1918, who was best-known for his research on vitamins. Her work on diet and teeth was in many ways an offshoot of her husband's research, and it culminated in three studies published in the Medical Research Council's Special Report Series in 1929, 1930, and 1934.

May Mellanby had a long-standing interest in the links between diet and dental caries. In a paper given in 1921, for example, she argued that despite the development of the dental profession and research "we have not yet fathomed the main cause of the appalling state of the teeth of civilised men of to-day". From experiments conducted on the diet of puppies, Mellanby concluded that vitamins were of fundamental importance in the development of healthy jaws and teeth. She extended her deductions to humans, pointing out that the Eskimos, who lived on a diet of meat and blubber, had perfect teeth, as did people living on the island of Lewis, where the diet consisted largely of fish, eggs, and oatmeal. In contrast, the urban poor in industrial districts, who had a diet which was rich in carbohydrates and deficient in milk, eggs, and animal fats, usually had poor teeth. She also drew attention to experiments which had appeared to show that the better teeth of Jewish children in Leeds was due to a diet rich in milk, eggs, and fat fish-all containing vitamins. ${ }^{50}$ Thus Mellanby's research focused attention on the effect of the diet on the teeth of growing children, rather than on the importance of dental care and treatment. In November 1926, for example, she told Walter Fletcher, secretary of the MRC, that "dental surgeons are ready to talk $\&$ talk about sugar $\&$ apples, but they do not seem ready to verify or otherwise their so called 'facts' \& 'theories". 51 The most important aspect of Mellanby's research on diet and teeth was the mistaken emphasis on the role of diet as a factor in the structure of teeth, and this conclusion was amplified by work carried out in the following decade.

Mellanby's theories were elaborated in three surveys published in the Medical Research Council's Special Report Series. The first of these, published in 1929, was largely concerned with research on the diet of dogs, but Mellanby also claimed that observations on humans confirmed the deductions drawn from the experiments on animals. She argued that the structure of teeth was an important element in dental caries, since the dietetic factors that resulted in poorly calcified teeth also influenced resistance by decreasing their

$49 \mathrm{~J}$ Wheatley, 'Dental caries and sweets', Med. Offr., 1921, 25: 199-200.

50 M Mellanby, 'The effect of certain dietetic factors on the development of teeth and jaws', Med.
Offr., 1921, 25: 231-3.

51 PRO FD 1/5001, M Mellanby to W Fletcher, 3/11/26. See also Webster, 'The health of the school child', op. cit., note 6 above, p. 77. 
defensive powers. She concluded that "the evidence suggests the possibility that perfect teeth and jaws may be deliberately produced in man, especially by suitable diets during the period of their development, and that similar diets may confer upon fully erupted teeth increased resistance to infective and other harmful processes". 52 In the second survey, published in 1930, Mellanby reported on her experiments with other mammals including rabbits and rats, arguing that they indicated the tooth structure of all mammals was controlled by the same dietetic and environmental factors. ${ }^{53}$ Finally in the third report, published in 1934, Mellanby looked more closely at diet and teeth in humans. She argued that perfectly arranged and calcified teeth could be produced by adding substances containing fat-soluble vitamin, calcium and phosphorous such as milk, eggs, fish and animal fats to the maternal diet. She concluded that "with better structure of dental tissues and increased resistance to bacterial invasion there is every reason to believe that both dental caries and pyorrhoea will cease to be the scourge they are at the present time". 54

Since the MRC funded Mellanby's research, it was not surprising that it was enthusiastic about her findings. In its annual report for 1932-33, the MRC stated that it regarded this work "as of much promise for the substantial reduction of the present scourge of dental caries". 55 The research was widely publicized. Some newspapers attempted to tie Mellanby's investigations in with what was already known about the importance of cleaning the teeth. In May 1931 The Times tried to square the circle by stating that "common cleanliness, and natural diet from infancy onwards, will do very much to prevent dental caries". ${ }^{56}$ However Mellanby's findings and emphasis were contested by other researchers and individuals. Norman Bennett, for example, accepted that vitamin D was important, but argued that the cause of caries was bacterial action and that natural cleaning by eating fibrous foods prevented decay, so that both structure and environment played a part. In July 1935 he wrote of the Birmingham survey that the statistics dealing with the reduction of caries were convincing, but argued that "they are not the whole story of dental caries, and dental caries would not be abolished by feeding all the babies in the country on cod-liver-oil". 57 Another prominent dentist pointed to weaknesses in Mellanby's theories, noting that "so far the way in which minute structure may influence liability to caries has not been explained". 58

Some groups had their own reasons for being critical of Mellanby, so that their evidence has to be treated with caution. The Anti-Vivisection Journal, for instance, was critical of Mellanby's experiments with animals, and asked why the MRC continued to fund them "long after they have become the butt of all serious opinion in dental medicine". 59 In addition, other medical journals displayed an ambivalence that may have been a sign of

52 M Mellanby, Diet and the teeth. An experimental study. Part I. Dental structure in dogs, London, HMSO, 1929, MRC special report series no. 140, pp. 3-10, 305.

${ }_{53}$ M Mellanby, Diet and the teeth. An experimental study. Part II. A. Diet and dental disease. B. Diet and dental structure in mammals other than the dog, London, HMSO, 1930, MRC special report series no. 153 , pp. 3-7, 93.

$54 \mathrm{M}$ Mellanby, Diet and the teeth. An experimental study. Part III. The effect of diet on dental structure and disease in man, London,
HMSO, 1934, MRC special report series no. 191, pp. 4, 172-8.

55 Medical Research Council, Annual report 1932-33, London, HMSO, 1934, p. 29.

56 PRO FD 1/5002, cutting from The Times, 20/5/31.

57 PRO FD 1/4986, N Bennett to D Munro, $16 / 7 / 35$.

58 Ibid., offprint from the $B r$. den. J., 1/5/35, p. 9.

59 PRO FD 1/5002, cutting from the AntiVivisection Journal, 5/32, pp. 57-8. 
their own doubts about dental research. In its review of Part 1 of Mellanby's study, the Medical Officer argued that children with rickets did not necessarily have dental caries, and it queried whether the experiments on animals outlined in Part II could be applied to man. In its review of Part III, on the other hand, the journal accepted that Mellanby had produced the standard work on experimental dentistry, and that, while she would not satisfy all her critics, she "has got near to proving her hypothesis". ${ }^{60}$ Arguably this may have illustrated the extent to which the journal, and MOHs in general, were out of touch with dental and medical research.

An interesting question is how far Mellanby's work had a practical influence on the Board of Education's policy-makers. In his annual reports Sir George Newman monitored the social surveys sponsored by the MRC, and research on dental health, and there was evidence that he was influenced by Mellanby's work. In his annual report for 1924, for example, Newman suggested that it was conceivable that if expectant and nursing mothers and children had suitable diets "it may be possible enormously to reduce the incidence of dental disease, if not to eliminate it altogether". ${ }^{61}$ Two years later, he noted that investigations had found that children with rickets also usually had severe dental caries, and observed of Mellanby's research that evidence was accumulating that "the basic cause is as a rule a nutritional defect, acting during ante-natal or early post-natal life". ${ }^{2}$ By the early 1930s, he noted that diet could help the formation of healthy teeth, and suggested that vitamin D should be supplied in the form of cod-liver oil. In 1931, he wrote that dental caries "is not entirely due to local conditions in the mouth; that immunity, or at least freedom from decay, can to some extent be promoted by conditions affecting general metabolism, and that in these conditions diet plays an important part". He wondered whether research might show if freedom from dental disease was geographical, if it was affected by environmental factors, whether perfect teeth could be inherited, and if "habits of life" could confer immunity. ${ }^{63}$

Further evidence on the possible links between research and policy is provided by the Board's Consultative Committee. It asked May Mellanby for help with a forthcoming memorandum, and her contribution provides insights into her distinctive stance on the issue of diet and dental health. She wrote that cleaning the teeth was of little value, and could be positively harmful, since toothbrushes were ideal breeding-grounds for bacteria and could damage the gums. Mellanby reiterated that if the initial structure of the teeth and gums was good they were less likely to decay, that satisfactory development could be guaranteed with the correct diet, and that the best way of avoiding dental caries was by ensuring that the diet "will induce perfect calcification of the tissues and maintain their resistance to disease". She concluded that the structure of the teeth was controlled by diet, mainly vitamin $\mathrm{D}$, and that children with rickets also often had dental caries. ${ }^{64}$

\footnotetext{
60 PRO FD 1/5001, cutting from the Med. Offr., 26/4/30; PRO FD 1/5003, cutting from the Med. Offr., 10/2/34.

61 Health of the school child, 1924, London, HMSO, 1925, p. 71.

62 Health of the school child, 1926, London, HMSO, 1927, p. 23.

${ }^{63}$ Health of the school child, 1930, London,
}

\footnotetext{
HMSO, 1931, p. 30; Health of the school child, 1931, London, HMSO, 1932, pp. 86-7.

64 Contemporary Medical Archives Centre, The Wellcome Institute for the History of Medicine, London (hereafter CMAC), PP/MEL/F4, M Mellanby, 'Memorandum on a) the care of the teeth and $b$ ) the prevention of rickets in young children up to the age of eight', pp. 2-9.
} 


\section{John Welshman}

Although it would appear that Mellanby's work did have an important influence on the Board, there is also evidence that Newman may have been dubious. While he suggested that health education should stress the importance of Vitamin D, and recommended eggs, milk, butter, and cod-liver oil, he told school doctors that this advice "should of course supplement, and not replace, the teaching on dental hygiene that is already being given". 65 In general, Newman suggested that education should continue to stress the importance of toothbrushes and of the foods that helped to clean the teeth. Moreover, when the third part of Mellanby's study was published, the Chief Medical Officer noted that while structure was important "it would, I think, be disastrous if it were generally taught that the environment of the teeth is a matter of little importance in influencing the onset and development of caries". 66 Indeed Newman's attitude to Mellanby's research led to friction with her husband. In January 1935, when Edward Mellanby asked Newman why his wife's work was criticized so often, the latter replied, "I am indeed sorry if you have discovered anything imperfect, incomplete or inequitable in my reference to Mrs Mellanby's magnificent work". 67

While the Board was reluctant to stress diet and teeth at the expense of dental care, increasing interest in nutrition meant that some other writers did link diet and dental health. In 1936 for example, the author of a study of poverty and disease noted that "a prominent cause of caries is a food deficiency, and the measurement of dental decay will be a measurement of deficient diets". ${ }^{68}$ On the other hand, some nutritionists now reversed Mellanby's emphasis, and argued that dietary deficiency in early childhood had more of an impact on the condition of a child's teeth than at the ante-natal stage. John Boyd Orr, for example, concluded in his famous survey that the diets of lower income groups, lacking minerals and vitamins, were not likely to promote the growth of sound, healthy teeth, and a high incidence of dental caries was therefore likely. ${ }^{69}$ There was evidence in the late 1930s that Mellanby herself was shifting her ground. In November 1938 she claimed to Norman Bennett that she had "always stated that many factors must play a part in the production of dental caries and that to put down the prevalence of dental caries to one cause alone would be absurd". ${ }^{70}$

By the 1940s the dental profession as a whole disagreed with Mellanby's earlier findings. Indeed it was revealing that Norman Bennett had to reassure his colleague, telling her in October 1946, "I think your work is appreciated-it is by me at any ratebut it is not, I think, the whole story, and you never said it was". ${ }^{71}$ Certainly, while Newman remained sceptical about the stress on the structure of teeth as a factor in caries, there is no doubt that Mellanby's work, linked with that of her husband on vitamins, was influential in the interwar period. In particular, it had had an unfortunate effect in directing attention toward the nutrition of mothers at the ante-natal stage and away from the active care of the teeth; mothers gained from this emphasis, but children lost out. In this respect, the impact of her research on policy was similar to that of the nutritionists, where the

65 Health of the school child, 1930, London, HMSO, 1931, pp. 30-1.

66 Health of the school child, 1933, London, HMSO, 1934, p. 130.

67 PRO FD 1/5003, G Newman to E Mellanby, $31 / 1 / 35$.

68 C E McNally, Public ill-health, London,

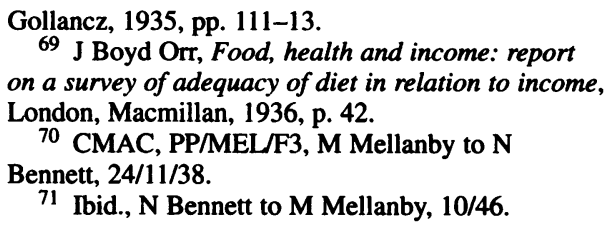

71 Ibid., N Bennett to M Mellanby, 10/46. 
conservative approach typified by the "Glasgow School" coincided with Government passivity on welfare. ${ }^{72}$ Indeed it arguable that in the late 1930 s the debate about the relative significance of dental hygiene and diet in the causation of caries provides a microcosm of the much wider controversy about whether individual habits or low wages were more significant factors in poverty.

\section{Financial Retrenchment and Regional Variations in Provision}

Much of this medical research was centred on London, and, while dental services in the capital were impressive, the substantial regional variations in the School Dental Service were also one of the most striking features of this period. Although London was relatively well-served, it was particularly difficult to provide dental services in rural areas. As we have seen, only seven counties had established treatment schemes by 1912, and in 1925 it was estimated that 46.7 per cent of children in the towns, but only 32.8 per cent in the counties, were covered by school dental schemes. Newman suggested that these local authorities should consider using more innovative methods such as small village clinics, itinerant dentists, and touring dental caravans. Some did set up imaginative schemes. The county of Ely for example, deployed a dental van which travelled 5,000 miles and carried out treatment at 46 schools in 1925, but it employed only one school dentist and only 19 per cent of the children requiring treatment received it. ${ }^{73}$ Other local authorities tried a variety of methods; Norfolk used a horse-drawn van, Lincolnshire and Cumberland motor vans, and Monmouthshire a lorry that had been converted into an ambulance. If transport was makeshift, facilities in rural schools also had to be improvised from whatever was available. In Lincolnshire, for example, the school dentist worked in classrooms, halls, or even rooms in which classes were being taught, while tables were improvised by placing blackboards across desks. ${ }^{74}$ In this county it took sixteen months to treat 40 per cent of the children aged five to seven, and these problems of distance and personnel certainly persisted in the 1930s.

The problems faced by the School Dental Service in both urban and rural areas meant that the Board was forced to consider selective schemes. It pointed out that in Cumberland, which had only three dentists, the 14 clinics inspected just under half the children, and the others were only treated in emergency cases. Newman admitted that it caused "some hardship" but commended the scheme to other LEAs, arguing that "it effects more real good and is productive of less hardship than any other method of overcoming the difficulty". ${ }^{75}$ In Warwickshire, eight-year-olds whose parents refused treatment were no longer examined at school medical inspections, and were denied access to school clinics, while those who had accepted treatment continued to have it. Newman quoted the SMO for Northamptonshire who had written that "unsatisfactory patients" whose parents had refused fillings and sent children only when they had toothache should

\footnotetext{
72 On this point see D Smith and M Nicolson, "The "Glasgow school" of Paton, Findlay and Cathcart: conservative thought in chemical physiology, nutrition and public health', Soc. Stud. Sci., 1989, 19: 195-237.
}

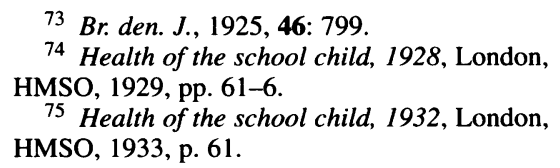




\section{John Welshman}

be "ruthlessly pruned away" ${ }^{76}$ The BDA supported the Board's discriminatory policy, and the British Dental Journal accepted that in view of the shortage of staff, school dentists had to work in a way that treated as many children as possible, but which conformed to "sound surgical principles". In January 1939, the journal noted that "a rigid insistence on acceptance of treatment in order to qualify for regular inspection and treatment and a severe discouragement of casuals should be made part and parcel of school dentistry". ${ }^{77}$ This policy was reiterated during the Second World War.

The CMO had conceded in 1930 that the School Dental Service "lags behind the other schemes for establishing and maintaining the health of school children", and many of these problems persisted into the late $1930 \mathrm{~s}^{78} \mathrm{~A}$ circular issued by the Board in January 1936 laid down minimum standards of one dentist for every 5,000 children in urban areas and for every 4,000 children in rural areas, but it admitted that "the School Dental Service is seriously incomplete in most parts of the country". ${ }^{79}$ Dentists writing in the British Dental Journal also remained critical of the School Dental Service. Norman Bennett, for example, argued that the emphasis placed on annual dental inspections was misplaced, and that incomplete schemes were also wasteful of resources, concluding that "the School Dental Service is, as everyone knows, incomplete; in fact, it does not do very much more than touch the fringe of the problem" ${ }^{80}$ In 1936 another dentist wrote that the growth of the service might create complacency "whereas the better frame of mind should be deep despondency at its inadequacy". 81

More generally, in the 1930s the School Dental Service became bound up with wider criticisms of the effectiveness of the School Medical Service, especially in the depressed areas. In particular, research by independent commentators revealed the true state of the School Dental Service in these regions and put further pressure on the Board. Allen Hutt pointed out that Burnley, Lancashire, could afford to employ only one school dentist, 3,000 children were ignored, and treatment was limited to extractions. ${ }^{82}$ Wal Hannington, leader of the National Unemployed Workers Movement and a member of the Communist Party, argued that unemployment and poverty among working-class families led to malnutrition which in turn was reflected in tuberculosis, anaemia, and dental caries. ${ }^{83}$ These writers were regarded as being politically motivated, but their testimony was confirmed by other investigators. The author of the Merseyside social survey found that there were not enough school dentists to inspect all the children every year, and that Liverpool operated a restrictive policy in which some children got regular inspection and treatment, but others were entirely uncared for. ${ }^{84}$

Other studies that have been used to illustrate the shortcomings of the School Medical Service with regard to the assessment of malnutrition and the provision of school meals

\footnotetext{
76 Health of the school child, 1933, London, HMSO, 1934, p. 125.

77 Br. den. J., 1933, 54: 588; Br. den. J., 1939, 66: 96.

78 Health of the school child, 1930, London, HMSO, 1931, p. 24.

79 Health of the school child, 1935, London, HMSO, 1936, pp. 112-14.

$80 \mathrm{~N}$ Bennett, 'Dental disease and the national health', Med. Offr., 1936, 56: 233-5.
}

\footnotetext{
81 A T Pitts, 'School Dental Service', Br. den. J., 1936, 61: 425-9.

${ }^{82} \mathrm{G}$ A Hutt, The condition of the working class in Britain, London, Martin Lawrence, 1933, p. 88.

${ }^{83} \mathrm{~W}$ Hannington, The problem of the distressed areas, London, Gollancz, 1937, p. 62.

${ }^{84}$ D Caradog-Jones (ed.), The social survey of Merseyside, London, Hodder \& Stoughton, 1934, vol. 3, pp. 39-40.
} 
also said much about the School Dental Service. The survey published in 1936 by Dr G C M M'Gonigle, SMO for Stockton-on-Tees, pointed out that the 31.5 per cent of children who were inspected in 1933 but found not to require dental treatment did not necessarily have perfect teeth. He claimed that returns made by SMOs did not indicate the incidence of dental caries or the percentage of children with perfect teeth, but merely showed the number and percentage requiring dental treatment. M'Gonigle argued that most schoolchildren in Durham and Stockton-on-Tees had dental caries, and he suggested that the situation was similar in other parts of the country, concluding that "the actual percentage of elementary school children with perfect dentition is . . . certainly very small". 85

In the late 1930s, calls for better dental services for both children and adults became part of the rhetoric of those radicals and groups who were critical of the existing state of health services. The report on health services by the independent group Political and Economic Planning, published in 1937, found that while wealthy people visited the dentist regularly and appreciated the importance of fillings, other social groups paid little attention to dental health. In the case of schoolchildren, the report argued that the inadequacy of the School Dental Service was "particularly unfortunate", and concluded that "the failure to treat and supervise them is laying up serious trouble for the future, not only over their teeth, but over their health in general" ${ }^{86}$ A report by the National Union of Teachers published in 1938 pointed out that it had resolved in 1912 that LEAs should be forced to provide school dental clinics; it blamed parents for not appreciating the value of treatment, but also showed that the percentage of children requiring but not receiving treatment remained stuck at about 36 per cent. ${ }^{87}$ New studies showed that even in certain London boroughs local dental services were inadequate. Finally some commentators not only pointed out existing problems, but also began to anticipate universal health services. In an article published in 1939, Norman Bennett argued for more frequent inspections, and for treatment for infants and adolescents. He concluded that "it is obviously necessary that the dental health of every citizen should be regarded as a single individual problem from infancy to old age, and as an essential part of medical care, and should be placed under one central directing authority". ${ }^{88}$ There were signs that the Board now accepted many of these criticisms. In the report for 1938, the CMO noted that if dental health was to improve, "much further progress will require to be made before the service can be regarded as adequate". 89

\section{School Dental Services and the Second World War}

Thus while many of the problems afflicting the School Dental Service persisted through the interwar years, there was also evidence by the late 1930s that some commentators were beginning to envisage dental care as an integral part of universal health services. On

85 G C M M'Gonigle and J Kirby, Poverty and public health, London, Gollancz, 1936, pp. 58-74.

86 PEP [Political and Economic Planning], Report on the British health services: a survey of the existing health services in Great Britain with proposals for future development, London, PEP, 1937, pp. 12, 182. See also S M Herbert, Britain's health, Harmondsworth, Penguin, 1939, p. 143.

\footnotetext{
87 National Union of Teachers, The School Health Services: their initiation, growth and character, London, NUT, 1938, pp. 33-9.

88 N Bennett, 'The place of dentistry in the School Health Service', Public Health, 1939, 52: 231-7.

89 Health of the school child, 1938, London, HMSO, 1940, p. 40.
} 


\section{John Welshman}

the other hand, with the outbreak of the Second World War in September 1939, schools were closed and clinics taken over as first-aid posts, while petrol rationing meant that the afternoon treatment sessions were shortened so that children could get home during the hours of daylight. These problems were exacerbated in the case of children who had been evacuated from the cities to the countryside; they did not have parents to take them to the dentist, and the householders with whom children were billeted could not be expected to pay. ${ }^{90}$ The Board recognized that it might be difficult to get the consent of parents and fell back on its previous discriminatory system; children of parents who had persistently refused treatment were eligible for emergency treatment only, but if children had previously had treatment, it was assumed that parents would agree. This system often broke down, leading to letters between the irate parents of evacuated children and local MOHs. ${ }^{91}$ The BDA continued to lobby for conservative treatment, but it was clear that in rural areas the School Dental Service was unable even to provide emergency treatment; instead this was performed by private dentists and paid for by parents.

In a circular issued in November 1939, the Board urged LEAs to resume conservative treatment as soon as possible, but it continued to discriminate against children who had not previously had treatment, and rejected the idea of compulsion. Indeed in drafts of a further circular, the Minister of Health admitted that he put in "examined" instead of "attended to" since the latter might "promise too much".92 Despite these circulars, the problems in providing dental treatment for the evacuees persisted into the early months of 1940. A circular issued in August 1940 stated that the use of dental attendants would release nurses for other purposes, but children whose parents had previously refused treatment could only have extractions. Indeed it suggested that if there was evidence that children had persistently neglected oral hygiene, "teeth which are technically saveable should not as a rule be filled". 93 The compulsory recruitment of dentists into the armed forces also began to affect the work of the School Dental Service towards the end of 1940. Although the Board asked LEAs to use private practitioners, the service continued to struggle; in the period 1938-45 the number of children inspected fell by 22.1 per cent and the number treated by 33.1 per cent. ${ }^{94}$

Some comments on the evacuees suggested that there was evidence of a sea-change in attitudes towards this aspect of health services. The dentist Frederick Bresse, for example, wrote in 1942 that "to press upon the mother of a child, whose bare toes were protruding from its boots, the need for dental cleanliness, with the advice to purchase a tooth-brush, seemed not merely futile, but almost cruel". 95 Similarly the author of a survey of social services in Oxford noted that the failure to provide dental treatment for adolescents was "one of the most serious anomalies in the health services of this country". 96 The Socialist Medical Association now argued that dentistry should be part of a comprehensive health

90 Health of the school child, 1939-45, London, HMSO, 1947, pp. 44-8.

91 PRO ED 50/208, W G Senior to C W

Maudslay, 6/9/39; ibid., J Forbes Marsden to the MOH for Buckinghamshire, 23/11/39.

92 Board of Education, Circular 1485, The School Dental-Service in war-time, 24/11/39; PRO ED 50/207, W Elliot to Earl de la Warr, 12/12/39.

93 Board of Education, Circular 1523, The School Medical and Dental Services in war-time, 21/8/40.
94 Health of the school child, 1939-45, London, HMSO, 1947, p. 46; Harris, op. cit., note 8 above, p. 195.

95 F Bresse, 'Some memories of the first London dental treatment centre for London elementary school children', Br. den. J., 1942, 72:157-61.

96 A F C Bourdillon, A survey of the social services in the Oxford district, Oxford University Press, 1938-40, vol 2, pp. 166-7. 
service, and stated in a pamphlet published in 1943 that "it should be available to every citizen, with priority at the outset to those sections, particularly the young, in whom dental care is most important". 97 The Inter-Departmental Committee on Dentistry (the Teviot Committee) urged the Government to establish comprehensive dental services, and the White Paper stated that a full dental service for the whole population, including regular conservative treatment, should form part of the new National Health Service. ${ }^{98}$ There was a greater recognition that many people, particularly in depressed areas, had lost all their teeth at an alarmingly low age. One survey published in 1948 found that 8 per cent of Welsh miners aged 15 to 24 , and 23 per cent of those aged 25 to 34 , had lost all their teeth. ${ }^{99}$ In the context of this heightened appreciation of the importance of dental health, and of problems of access to treatment, there were some signs that the School Dental Service did improve in the years after the Second World War. On the other hand, it is arguable that, despite the signs of progress, dental treatment remained the Achilles heel of the new School Health Service up to the 1974 NHS reorganization.

\section{A Local Case-Study: The School Dental Service in Leicester, 1913-48}

As we have seen, one of the most notable features of the School Dental Service, particularly before the Second World War, was the striking degree of regional variation in its effectiveness, and a local case-study also clarifies some of the other themes. For this purpose it is in some ways more helpful to look, not at a depressed rural region where low rates and logistical problems meant the local authority was unable to improve services, but at a progressive urban area where one might expect them to be highly developed. Throughout our period, Leicester County Borough was regarded as a go-ahead local authority with highly developed public health services. It was a large city, with a population of 239,169 inhabitants by 1931 , and was relatively prosperous with a diverse economy based on the hosiery trade, the manufacture of boots and shoes, and light industry. Its Education and Health Committees were dominated, initially by city fathers, and later by a combination of Liberal and Labour aldermen and councillors, and there was a consensus about the importance of public health services. In addition it was able to offer high salaries and attractive conditions of work that enabled it to appoint imaginative and confident SMOs. How then did the School Dental Service fare in Leicester, from its origins in 1913 to the outbreak of the Second World War?

As has already been noted, the local authority was progressive and had first appointed Dr Allan Warner as SMO in 1905, two years before it was technically required to do so by national legislation. Over the ensuing period, it gradually set up a system of medical inspections, provided children with treatment, gave them school meals and milk, developed physical education, and provided a range of "special" services. Although school medical inspections were supposed to include the teeth, these surveys were cursory as elsewhere, and the SMO wrote in 1910 that "it should be understood that a thorough

97 Socialist Medical Association, The socialised dental service, London, SMA, 1943, p. 8; Socialist Medical Association, $A$ socialised health service, London, SMA, 1944, p. 17.

98 Ministry of Health, A National Health Service: the White Paper proposals in brief, London, HMSO, 1944, p. 20.

99 W G Senior, 'The development of social dental service', Br. den. J., 1948, 85: 200-4. 


\section{John Welshman}

examination of the mouth was not made, but only the teeth that were obviously decayed were noted". ${ }^{100}$ Rival schemes for treating schoolchildren were put forward by the local authority and the local branch of the BMA, and two clinics were established, one in rooms owned by the Leicester Public Medical Service, and the other at the Town Hall. A parttime school dentist was among the staff appointed in May 1913, and if children required treatment a notice was sent to parents with a circular from the Education Committee. An "investigator" looked into the circumstances of individual families, and treatment was provided free if family income was less than $5 \mathrm{~s} 2 \mathrm{~d}$ per head after rent; if above this figure, a sliding scale ranging from $1 \mathrm{~s} 0 \mathrm{~d}$ to $6 \mathrm{~s} 6 \mathrm{~d}$ was applied for fillings and extractions. ${ }^{101} \mathrm{By}$ the end of the First World War the local authority employed a full-time dentist who was assisted by a panel of six local dentists appointed by the local branch of the BDA; in 1919 3,716 children were examined, 1,985 of whom needed treatment. Yet even Leicester's School Dental Service was overwhelmed by the number of children requiring treatment, and the SMO recognized that a comprehensive scheme would be prohibitively expensive. ${ }^{102}$

As in England and Wales as a whole, the interwar period brought some advances but other disappointments. By the mid-1920s, the School Dental Service in Leicester was dealing with more children; in 1926 for example, there were 15,358 routine inspections, 8,993 children were found to require treatment, of whom 6,061 (67.4 per cent) were treated. The school dentists also began to provide inspections for the mothers and infants who attended the Health Committee's infant welfare clinics, since medical examinations had revealed that their dental health was poor. Yet little conservative treatment was provided, either for the mothers and infants, or for schoolchildren, and the school dentists performed three times as many extractions as fillings. ${ }^{103}$ Although the local authority provided three dental clinics by the early 1930s, at the Public Medical Service rooms and in two local schools, facilities had improved little since the early years of the century. The school dentist wrote of the central dental clinic at Bond Street that "these premises are totally unsuitable for all the treatment which is undertaken", while the new dental clinic opened at the Catherine Street school was set up in a spare classroom, with a local church serving as a waiting room. ${ }^{104}$ With 34,000 schoolchildren and only four school dentists, Leicester also remained short of staff, and the Board's policy of restricting dental treatment to children whose parents had previously accepted it was taken up by the city. In January 1935 it agreed that it would not inspect or provide fillings for thirteen-year-old children who had previously refused treatment. ${ }^{105}$

An important factor in improving dental services was the attitude of the SMO. Dr Allan Warner gave dental health a high priority, partly because like Newman he had an exaggerated sense of its importance in preventing disease; he wrote that "it is being increasingly recognised that dental caries is a frequent cause of malnutrition and lowered

100 Leicester Education Committee, Annual report of the SMO, 1910, Leicester Corporation, 1911, pp. 1-9.

101 Leicestershire Record Office (hereafter LRO): minutes of the Medical Treatment and School Clinic Committee, 14/12/15.

102 Annual report of the SMO, 1919, Leicester Corporation, 1920, p. 27.

\footnotetext{
103 Annual report of the SMO, 1926, Leicester Corporation, 1927, p. 41.

104 Annual report of the SMO, 1936, Leicester Corporation, 1937, pp. 40-3.

105 LRO: minutes of the Medical Services subcommittee, 22/1/35, SMO, 'Restriction of the scope of the School Dental Service'.
} 
vitality, predisposing to many forms of infection, including tuberculosis". ${ }^{106}$ Yet he also echoed the CMO in blaming parents; in 1928, for example, he argued that the chief obstacle to an effective service was "the reluctance of parents to spending money and time in getting to, and from, and waiting at, dental clinics". ${ }^{107}$ There were some signs of a more sympathetic attitude, particularly on the part of Dr Kenneth Macdonald, the new SMO appointed in 1935. In March 1937, he gave a paper to local dentists in which he reviewed the national situation; 68 per cent of children inspected in 1935 had required dental treatment, and 314 of the 316 LEAs provided treatment, but there were only 646 full-time dentists, or one to every 7,600 children. Macdonald argued that equipment and health education could be improved, but also emphasized prevention, and was enthusiastic about orthodontics and conservative treatment, suggesting that "the primary object of the scheme is not to extract decayed teeth that are unsavable nor to relieve pain, but to save teeth". ${ }^{108}$ Macdonald was in tune with the more liberal approach advocated by the radicals in the later 1930s, and his ideas had an impact on local provision; his sub-committee agreed to appoint two additional school dentists, invite parents to inspections, and designate school dentists as dental surgeons.

One unexpected effect of the Second World War was that school dentists reported that children's teeth were cleaner on account of the reduced sugar consumption that followed wartime rationing. The senior school dentist wrote in 1945 that "dental decay, during wartime stringency, has not found the children's teeth the happy hunting ground which unrestricted dietary rendered the teeth of the pre-war child", and argued that this illustrated the benefits of preventive dental medicine. ${ }^{109}$ Mellanby's research seemed to be influential, since the improved dentition of five-year-old schoolchildren was attributed to the wartime extension of milk for expectant and nursing mothers and infants, along with cod-liver oil and orange juice. Yet despite these indications of progress, many of the problems that the School Dental Service in Leicester had faced in the earlier period also persisted in the first decade of the NHS. The first and greatest of these was the problem of recruiting school dentists. The Spens Committee had found that private dentists earned twice as much as public dentists, and this was reflected in the city; in 1945-48, five advertisements for staff produced only eight applications, and no appointments were made. Leicester had only half as many dentists as it required and 2,000 children were waiting for treatment at the end of 1948 . Indeed more rather than less emergency treatment was provided, and the senior school dentist noted that "the medical historian of the future will not readily understand the present unintelligent disposition of the dental forces". 110

Thus the local case-study does help to illuminate both the successes and failures of the School Dental Service from the early 1900 s to the Second World War. The establishment of the service illustrated how some local authorities acted before they were required to do so by national legislation, treatment expanded, and facilities gradually improved. Dr Warner gave dental health a high priority, while Dr Macdonald also displayed a

\footnotetext{
106 LRO: minutes of the Medical Treatment Committee, 18/12/17, A Warner, 'Report on dental treatment'.

107 Annual report of the SMO, 1928, Leicester Corporation, 1929 , pp. 6-7.

108 LRO: minutes of the Medical Services subcommittee, 20/7/37, E K Macdonald, 'Public dental
}

services and the Medical Officer of Health', 16/3/37, pp. $1-14$.

109 Annual report of the SMO, 1945, Leicester Corporation, 1946, p. 22.

110 Annual report of the SMO, 1948, Leicester Corporation, 1949, p. 61. 
sophisticated grasp of issues at the national level. During the Second World War the reduction in sugar consumption that accompanied rationing had a beneficial effect on the teeth of the city's children, and there were other signs of progress. Yet the case-study of Leicester also confirms some of the problems that have already been identified for England and Wales in general. The local branch of the BDA opposed the expansion of treatment, and Dr Warner was also critical of parents. Most of the treatment given consisted of extractions, and conservative treatment remained a low priority. Facilities in school clinics tended to be unimpressive, and Leicester remained seriously short of staff, so that it was forced to adopt selective schemes. Many of these problems persisted, and indeed intensified, in the postwar period.

\section{Conclusion}

The problem of providing dental health care for schoolchildren in England and Wales before the Second World War provides important insights into the operation of the School Medical Service as a whole. On the one hand, the system of medical inspection that was created in 1907 did include an examination of the state of childrens' teeth, and from 1912 many local authorities began to establish dental clinics. Some local authorities followed the lead of Cambridge in providing quite impressive dental services, while others, such as Heston and Isleworth, began to branch out into more progressive areas, including orthodontic treatment. Even in the more backward local authorities, the new provision of inspections and treatment was an improvement on what had gone before. And there was evidence of a forward movement in thinking regarding dental care, that grew gradually in the late 1930s, and crystallized during the Second World War. In these respects, the School Dental Service before 1940 might be viewed as a testing ground or prototype for later developments in the provision of dental services for both children and adults.

Yet at the same time it is clear that dental inspection and treatment was arguably the least impressive aspect of the School Medical Service up to and beyond the Second World War. As we have seen, one of the key problems was manpower, since rather than choosing to work for a local authority, dentists preferred to enter private practice where salaries were higher and where their interests were protected by the BDA. This was a situation in which the Board of Education largely acquiesced, by encouraging local authorities to employ auxiliaries and other less-highly qualified staff, and by advocating the adoption of various restrictive schemes. While it is difficult to measure the impact of dental research as a whole, the work of May Mellanby can with hindsight be seen as both influential and damaging, in the way that it focused attention on diet and downplayed the importance of toothbrushes and dental hygiene. Moreover the School Dental Service serves to confirm the existence of the regional variations in provision that were such a feature of health services as a whole before the Second World War. Those authorities that provided orthodontic treatment and other progressive services tended to be the exceptions to the general rule, and the experience of many schoolchildren would have been limited to inspections and extractions. And this conclusion is if anything strengthened by case studies of provision on the ground where the performance of "progressive" local authorities like Leicester tends to be less impressive than might be expected. 
But while we may debate the achievements and failures of the School Dental Service, it is undeniable that, in illuminating gaps in current knowledge about the development of health care, this topic has a more general relevance for medical historians. Perhaps most obvious among these is the experience itself of dental inspection and treatment, and the implication of these brief but formative episodes for children in the wider context of life inside and outside school. This lost aspect of the story could be recovered through oral testimony, and might serve to confirm or question the powerful Foucaldian argument that dental inspections acted as mechanisms of control and surveillance. In the same way, historians might be able to recapture the world of the school dentist, his feelings of optimism or depression regarding the nature of his work, and his sense of status compared to his counterparts in private practice. And the history of dental care might in future be broadened by age, gender, class, and ethnicity, so that it encompasses the experience of adults as well as children, of women as much as men, of both the middle and the working class, and of ethnic minority groups as well as the host community. Dental health remains a neglected issue of medical history, both as an important component of morbidity in the general context of working-class life, and as an under-researched aspect of the development of health care. As such, a better historical account may well provide lessons for those whose work on more contemporary issues continues to highlight dental care as an area that reveals the conjunction of important themes of poverty, health, and social class. 